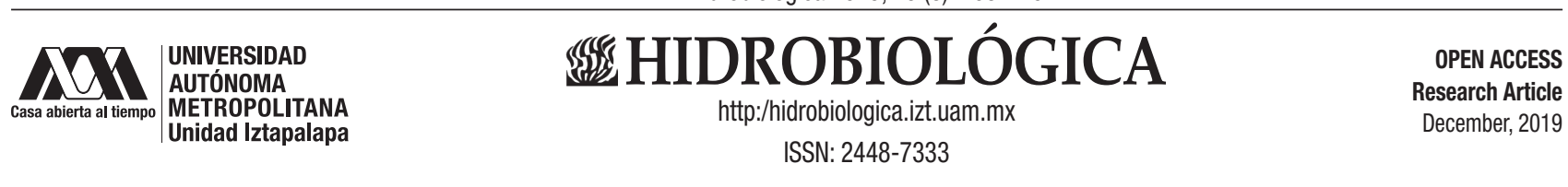

\title{
Intra-annual variation of chlorophyll-a and nutrients in a hydraulically perturbed river-floodplain system in the Grijalva River basin
}

\author{
Variación intra-anual de la clorofila-a y nutrientes en un sistema río-llanura de inundación hidráulicamente perturbado \\ en la cuenca del río Grijalva
}

\author{
Allan K. Cruz-Ramírez¹, Miguel Ángel Salcedo², Alberto J. Sánchez², Juan de Dios Mendoza³ ${ }^{3}$ Everardo Barba4 Nicolás Álvarez-Pliego² \\ and Rosa Florido ${ }^{2}$
}

\begin{abstract}
Doctorado en Ecología y Manejo de Sistemas Tropicales, División Académica de Ciencias Biológicas, Universidad Juárez Autónoma de Tabasco. $0.5 \mathrm{~km}$ carretera Villahermosa-Cárdenas, Villahermosa, Tabasco, 86150. México.

2 Diagnóstico y Manejo de Humedales Tropicales, División Académica de Ciencias Biológicas, Universidad Juárez Autónoma de Tabasco. $0.5 \mathrm{~km}$ carretera Villaher mosa-Cárdenas, Villahermosa, Tabasco, 86150. México

Recursos Hídricos y Edáficos, División Académica de Ciencias Agropecuarias. Universidad Juárez Autónoma de Tabasco. Carretera Villahermosa-Teapa Km 25, R/a, La Huasteca 2a Sección, Centro, Tabasco, 86290 México.

${ }^{4}$ Manejo Sustentable de Cuencas y Zonas Costeras. El Colegio de la Frontera Sur, Unidad Villahermosa. $15.5 \mathrm{~km}$ carretera Villahermosa-Reforma, Villahermosa, Tabasco, 86280. México,
\end{abstract}

${ }^{*}$ Corresponding author:

Alberto J. Sánchez: e-mail:

alberthoj.sanchez@gmail.com

To quote as:

Cruz-Ramírez A. K., M. A. Salcedo, A. J. Sánchez, J. de D. Mendoza, E. Barba, N. Álvarez-Pliego \& R. Florido. 2019 Intra-annual variation of chlorophyll-a and nutrients in a hydraulically perturbed river floodplain system in the Grijalva River basin Hidrobiológica 29 (3): 163-170.

DOl: 10.24275/uam/izt/dcbs/hidro/2020v29n3/ Cruz

Vol. 29 No. $3 \bullet 2019$

\section{ABSTRACT}

Background: The lateral connectivity in the Maluco river-floodplain system was partially reduced by the highway built on a natural barrier. Goal: To determine if the concentrations of chlorophyll-a (Chl-a) and nutrients contrast in different water levels (WL) during a hydrologic year in the Maluco river-floodplain system. Methods: The WL, Chl- $a$, and nutrients $\left(\mathrm{NO}_{2}^{-}, \mathrm{NO}_{3}{ }^{-}, \mathrm{NH}_{4}^{+}\right.$, and TP) were simultaneously measured six times in two sites during two years. The expected differences of $\mathrm{Chl}-\mathrm{a}$ and nutrients concentrations, related to the intra-annual fluctuation of the WL, were tested through multivariate techniques. The hypothesis holds that there will be no intra-annual differences of $\mathrm{Chl}-\mathrm{a}$ and nutrients due to the reduction of lateral interconnection by the physical effect of the embankment. Results: No variable was discarded during PCA. The intra-annual distribution of samples was similar according to the similarity profile routine. Furthermore: 1) more than $54 \%$ of the Chl- $a$ and TP values indicated hypereutrophic conditions throughout the year, and 2) none of the values of WL surpassed the height of the bankfull (4.5 masl). The maximum concentrations of Chl-a were registered at the minimum WL values. Conclusions: The intra-annual similarity of $\mathrm{Chl}-a$ and inorganic nutrients can be linked to the disconnection between the floodplain and the Grijalva river since the bankfull was not overflowed throughout the sampling time. The intra-annual trend independent at the time of persistence of the high Chl- $a$ and TP concentrations in the river-floodplain system opens up the opportunity to estimate the minimum input flow required to biogeochemical processes in a long-term study.

Key Words: Embankment, eutrophication, fragmentation, Grijalva river, hydraulic disconnection.

\section{RESUMEN}

Antecedentes: La interconexión lateral en el sistema río-llanura de inundación Maluco fue reducida parcialmente por una carretera construida sobre una barrera natural. Objetivo: Determinar si las concentraciones de clorofila- $a$ (Cla- $a$ ) y nutrientes contrastan en diferentes niveles de agua (NA) durante un año hidrológico en el humedal fluvial. Métodos: El NA, Cla-a y nutrientes $\left(\mathrm{NO}_{2}^{-}, \mathrm{NO}_{3}{ }^{-}, \mathrm{NH}_{4}^{+}\right.$y PT) se midieron simultáneamente seis veces en dos estaciones durante dos años. Las diferencias esperadas de las concentraciones de Cla-a y nutrientes, relacionadas a la fluctuación intra-anual del NA, fueron analizadas por medio de técnicas multivariadas. La hipótesis sostiene que no se detectarán diferencias intra-anuales de Cla-a y nutrientes debido a la reducción de la interconexión lateral por el efecto físico del terraplén. Resultados: Ninguna variable fue descartada con el ACP. La distribución intra-anual de las muestras resultó similar según la rutina de perfiles de similitud. Coincidentemente: 1) más del $54 \%$ de los valores de Cla-a y PT indicaron condiciones hipereutróficas durante todo el año y 2) ninguno de los valores de WL sobrepasó la altura del terraplén (4.5 msnm). Además, las concentraciones máximas de Cla-a se registraron en los WL mínimos. Conclusiones: La similitud intra-anual de la Cla-a y los nutrientes inorgánicos se puede vincular a que la llanura de inundación estuvo desconectada del río Grijalva, ya que la inundación no sobrepasó la altura del terraplén durante todo el tiempo de muestreo. La tendencia intra-anual independiente al tiempo de la persistencia de las altas concentraciones de Cla-a y PT en el sistema río-llanura de inundación abre la oportunidad de estimar el caudal de entrada mínimo requerido para restaurar los procesos biogeoquímicos en un estudio a largo plazo.

Palabras Clave: Bordo, desconexión hidráulica, eutrofización, fragmentación, río Grijalva. 


\section{INTRODUCTION}

In riverine wetlands, the intra-annual distribution patterns of the concentration of physicochemical variables in the water column differ mainly between the low and high water level conditions, whose surface hydraulic interconnection maintains its natural flow (Brinson, 1993; Junk \& Wantzen, 2004; Thomaz et al., 2007). In this way, the values of chlorophyll-a (Chl-a) and nutrients are influenced by the lateral exchange of water due to temporal flooding, residence times and inputs of organic matter by runoff (Tubatsi et al., 2014; Fritz et al., 2018). For example, the increase of algal biomass has been frequently recorded during the low water level (WL) condition (Brito et al., 2014; Roach et al., 2014; Cruz-Ramírez et al., 2019). On the contrary, its decrement has been recorded in conditions of high WL (for example, Noe et al., 2013) since its fluctuation has been linked to the flood pulse that allows the dispersion of the planktonic community in areas with seasonal inundation (Junk \& Wantzen, 2004; Noe et al., 2013). Moreover, the enrichment in nitrogen and phosphorus has been indistinctly mentioned as a dominant abiotic processes tied to the spatial-temporal variability in the WL of the river-floodplain systems (for example, Brito et al., 2014; Tubatsi et al., 2014; Cruz-Ramírez et al., 2019).

However, the high variability of the concentrations of nutrients in short times regarding the inter-annual fluctuation of the WL can enhance the eutrophication (carbon, nitrogen, phosphorus), which in turn increase the phytoplankton biomass (Dodds, 2007; Cruz-Ramírez et al., 2019). Additionally, wastewater discharges, diffuse input of agricultural nutrients, runoffs and hydraulic disconnection are other causes associated with the enhancement of nutrients in river-floodplain systems (Cetin 2009; Sharma et al., 2010; Sánchez et al., 2012; Jeppesen et al., 2015; Lázaro-Vázquez et al., 2018).

Frequently, the hydraulic disconnection has been related to physical obstruction by infrastructure constructed for different purposes. The infrastructure built to store water or prevents floods as well as the urban sprawl has been the main anthropogenic causes that have impaired the natural variations in the WL in perturbed river-floodplain system (Poff et al., 2007). For instance, the reduction of the flow referential values, as well as changes to water quality in rivers was associated with a South Africa impoundment (Mantel et al., 2010). Moreover, the construction of roads and levees has caused hydraulic disconnection between the river and its flood area in USA (Coffin, 2007; Blanton \& Marcus, 2009), which in turn has originated a decrement of the natural variation of the WL linked to the increment of the concentration of nutrients and eutrophication (Jeppesen et al., 2015).

The Maluco river-floodplain system was temporally interconnected with the Grijalva River until the early 80's, when its hydraulic interconnection was drastically reduced from three to one storm drains placed under the highway, which was built on a natural barrier (Gil \& Saenz, 1872). Since this time, the highway has worked as an embankment that has restricted the lateral connection, due to that the bankfull stage was heightened up to $4.5 \mathrm{~m}$ above the sea level. Although, the construction of channels and embankments has been the most common public policy to avoid inundations in the cities located in the floodplain of the Grijalva Basin (Sánchez et al., 2015), there are no environmental data available on the Maluco river-floodplain system before the 80 's to corroborate the magnitude of the awaited environmental impacts by the restriction of the hydraulic interconnection.
The reduction of lateral interconnection due to the physical effect of the embankment reduces the probability that the Grijalva River has overflowed above the bankfull stage, which opens the hypothesis that there will be no intra-annual differences of $\mathrm{Chl}-\mathrm{a}$ and nutrients. To test the hypothesis, the concentrations of $\mathrm{Chl}-a$, nitrogen and phosphate nutrients were measured at different WLs of a hydrological year over a 2-year period in the Maluco river-floodplain system.

\section{METHODS AND MATERIALS}

Study area. The Maluco river-floodplain system is located in the floodplain of the Grijalva Basin. The Grijalva River is originated $17.6 \mathrm{~km}$ upstream the study area, where the dammed Mezcalapa-Carrizal and the freeflowing Sierra-Pichucalco rivers merge. The Mezcalapa-Carrizal Rivers have four dams built in the mountains of the Grijalva Basin, which stored up to $26,081 \mathrm{~mm}^{3}$ at the ordinary high WL (Navarro \& Toledo, 2008). Both rivers drain an average $17,364.17 \mathrm{~mm}^{3} / \mathrm{y}$ downriver (DOF, 2018). Whereas, the Sierra-Pichucalco Rivers drain an average $3,186.76 \mathrm{~mm}^{3} / y$ (DOF, 2018) before merging to the Mezcalapa-Carrizal River. In the study area (1,580.4 ha) Eichhornia crassipes (Mart.) Solms, Pistia stratiotes L., Nymphaea ampla (Salisb.) DC., Thalia geniculata L.and Typha domingensis Pers. are the recorded aquatic macrophytes. The adjacent lands of the lagoon are used for growing crops and raising livestock (Palma-López et al., 2007). As was mentioned above, the lateral exchange of water in the Maluco river-floodplain system was restricted by a highway built in the early 80 's.

The Maluco river-floodplain system is located $23 \mathrm{~km}$ downstream from the Metropolitan Area of Villahermosa city with a population of 755,425 inhabitants and 77 sewage discharge points. These 77 sites drain $282 \mathrm{Mm}^{3} / \mathrm{y}$ into the Grijalva river and nearby wetlands, of which $18 \%$ have limited or no treatment (INEGI, 2011; 2012).

Sampling design. The Maluco river-floodplain system was sampled bimonthly during two hydrological years (2004 and 2005) to measure the intra-annual variation of average WL (Fig. 1). Two sites $\left(18^{\circ}\right.$ $05^{\prime} 24.49^{\prime \prime} \mathrm{N}, 92^{\circ} 45^{\prime} 34.30^{\prime \prime} \mathrm{W}$ and $18^{\circ} 05^{\prime} 22.47^{\prime \prime} \mathrm{N}, 92^{\circ} 45^{\prime} 10.45^{\prime \prime}$ W) were simultaneously sampled in six sampling times (Fig. 2), which summed a total of 24 records per physicochemical or biological variable. On each occasion the WL $(\mathrm{m})$ was measured by a depth sounder (PS-7). The maximum WL in the wetland $(13 \mathrm{~m})$ was referenced at 4.5 $\mathrm{m}$ above sea level (masl), which is equal to the altitude of the embankment. Water samples were also collected at the medium depth with a van Dorn bottle and stored at $4^{\circ} \mathrm{C}$ for laboratory analysis. Nitrite $\left(\mathrm{NO}_{2}{ }^{-}\right)$, nitrate $\left(\mathrm{NO}_{3}^{-}\right)$, ammonium $\left(\mathrm{NH}_{4}{ }^{+}\right)$and total phosphorus (TP) concentrations in $\mathrm{mgL}^{-1}$ were determined according to APHA (1998) procedures; whereas, $\mathrm{Chl}-\mathrm{a}\left(\mu \mathrm{gL}^{-1}\right)$ analyses were done immediately following the recommendations of SCOR-UNESCO (1966).

Data analysis. The intra-annual variation of the physicochemical variables $\left(\mathrm{NO}_{2}{ }^{-}, \mathrm{NO}_{3}{ }_{3}, \mathrm{NH}_{4}{ }^{+}, \mathrm{TP}\right.$ and, $\left.\mathrm{Chl}-\mathrm{a}\right)$ among the six sampling times was analyzed through a Principal Components Analysis (PCA). The PCA was based on a correlation matrix, and the dissimilarities were calculated based in the Euclidean distance after standardization of the five original variables (Legendre \& Legendre, 2003). Additionally, the principal components $(\mathrm{PC})$ with eigenvalues $>1$ (Kaiser-Guttman criterion) and significant variation (Bartlett; $p<0.05$ ) were selected (Legendre \& Legendre, 2003). Then, the variables with absolute values in the eigenvectors greater than $10.4 \mid$ and by having significant contributions 


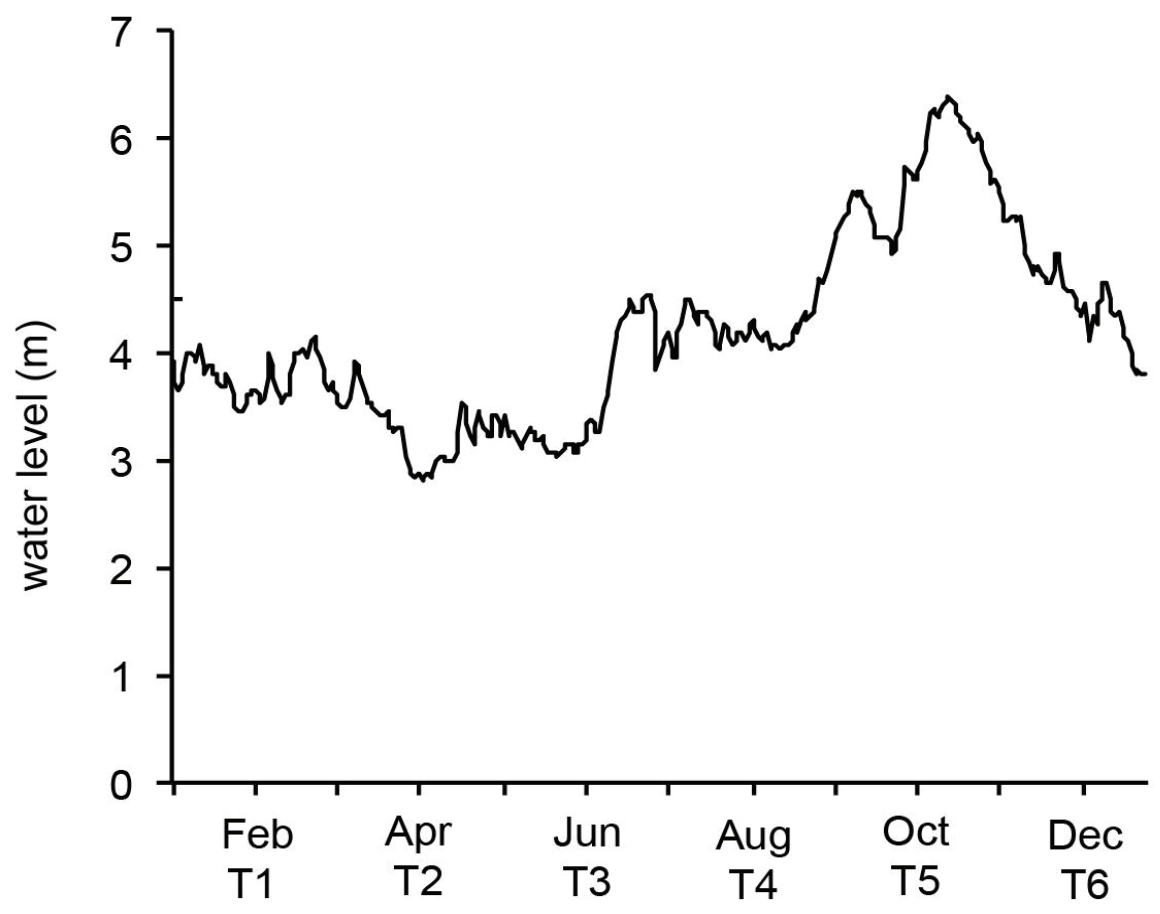

Figure 1. Intra-annual variation of average water level of Grijalva River from 1995 until 1999 in the 30083 hydrometric station in the Grijalva River. Black line= water level, T= sampling times. Data source: CONAGUA (2012).

were considered in the selected PC's (Weilhoefer et al., 2008). These analyses were carried out with the JMP v10 Software (SAS Institute, 2012). Before the PCA calculation, the correlation coefficients $(>|0.3|)$ and the determinant of the correlation matrix $(0.325)$ were used to find the collinearity among the five variables analyzed. The multicollinearity was reviewed by means of Bartlett's test of sphericity $(p=0.011)$ and the Kaiser-Meyer-Olkin test (0.523), since the variables showed a medium degree of inter-correlation (Tabachnick \& Fidell 2014). The last four analyses were carried out through the IBM SPSS Statistics software v24 (IBM Corp, Armonk, NY, USA). Finally, the similarity profile routine (SIMPROF) was used to determine the possible significant differences among the groups. The SIMPROF was applied with a significant level of $p<0.05$ (Clarke et al., 2008) through the program PRIMER v6.1.6 (Clarke \& Gorley 2006). The interpretation of the variables selected was complemented by the calculation of the mean, standard deviation and error of each sampling time (four data by sampling time).

\section{RESULTS}

No variable was discarded during PCA. The PC1 (eigenvalue $=2.101$ ) explained $42 \%$ of the significantly variation in the riverine wetland (Bartlett; $\mathrm{p}=0.006)$. In this first axis (PC1), Chl- $a(0.567), \mathrm{NH}_{4}^{+}(0.502)$, and $\mathrm{NO}_{3}^{-}(0.497)$ were positively associated, while $\mathrm{NO}_{2}^{-}(-0.402)$ was negatively associated. Whereas, the PC2 (eigenvalue $=1.265$ ) described $25.3 \%$ of the variation, but it was not significant (Bartlett; $p=0.15$ ). This second axis showed a positive relationship with $\mathrm{NH}_{4}{ }^{+}(0.463)$ and negative with TP $(-0.738)$.
The analysis of the distribution of samples indicated an intra-annual similarity (SIMPROF; $p=0.149$ ) since $100 \%$ of samples were grouped (Fig. 3). The second and third sampling times presented the highest concentrations of $\mathrm{Chl}-\mathrm{a}, \mathrm{NH}_{4}^{+}$, and $\mathrm{NO}_{3}$. Indeed, in the $\mathrm{CP} 1$, the low percentage of the explained variation was associated with the minimal dispersion of the samples with the time.

It stands out that $54 \%$ of the total of $\mathrm{Chl}$-a records exceeded 25 $\mu \mathrm{gL}^{-1}$, up to a maximum concentration of $208 \mu \mathrm{gL}^{-1}$ (Fig. 4). However, their concentrations showed a tendency to be higher during the first three sampling times (Fig. 4). Likewise, $66.7 \%$ of the total TP concentrations were greater than or equal to $0.1 \mathrm{mgL}^{-1}$, although the two maximum concentrations $\left(>1 \mathrm{mgL}^{-1}\right)$ were measured in the fifth sampling time (Fig. 4). The $25 \%$ of $\mathrm{NH}_{4}^{+}$concentrations were greater than or equal $1 \mathrm{mgL}^{-1}$, while only the $4.2 \%$ of the $\mathrm{NO}_{3}^{-}$values exceeded this value (Supplement 1). $\mathrm{NH}_{4}{ }^{+}$values greater than $1 \mathrm{mgL}^{-1}$ were quantified in four of the six sampling times $(2,3,5$ and 6$)$. Instead, $\mathrm{NO}_{3}{ }^{-}$concentrations only surpassed $1 \mathrm{mgL}^{-1}$ in the second sampling (Supplement 1). Finally, none of the $\mathrm{NO}_{2}{ }^{-}$values exceeded $1 \mathrm{mgL}^{-1}$, and they recorded similarity among the six times (Supplement 1).

The maximum values of WL were lower than the overflow level of the bankfull stage, which was estimated at $13 \mathrm{~m}$ (Supplement 1). Although higher concentrations of $\mathrm{Chl}-\mathrm{a}$, and TP were recorded throughout the study time, the highest values of $\mathrm{Chl}-a, \mathrm{NO}_{3}{ }_{3}^{-}$and $\mathrm{NH}_{4}{ }^{+}$coincided with the minimum values of WL, quantified in the 2 and 3 sampling times (Fig 4). 


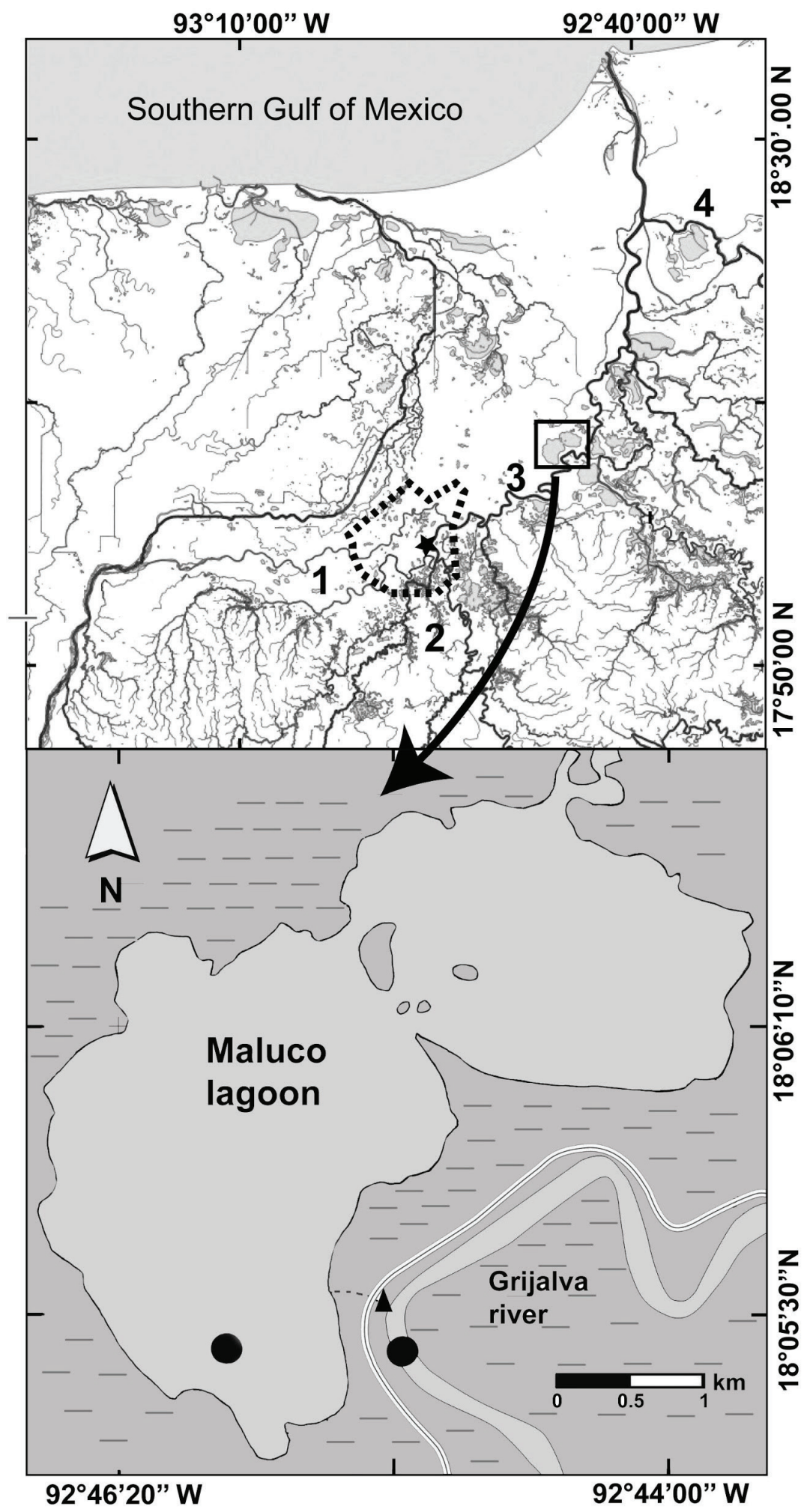

Figure 2. Location of study area. Embankment= $=$ floodplain= $=$ Metropolitan Area of Villahermosa= IIII, hydrometric station= black star, sampling sites in the river-floodplain system= black circle. Map modified from http://antares.inegi.org.mx/analisis/red_hidro/SIATL/\# (INEGl, 2013). 


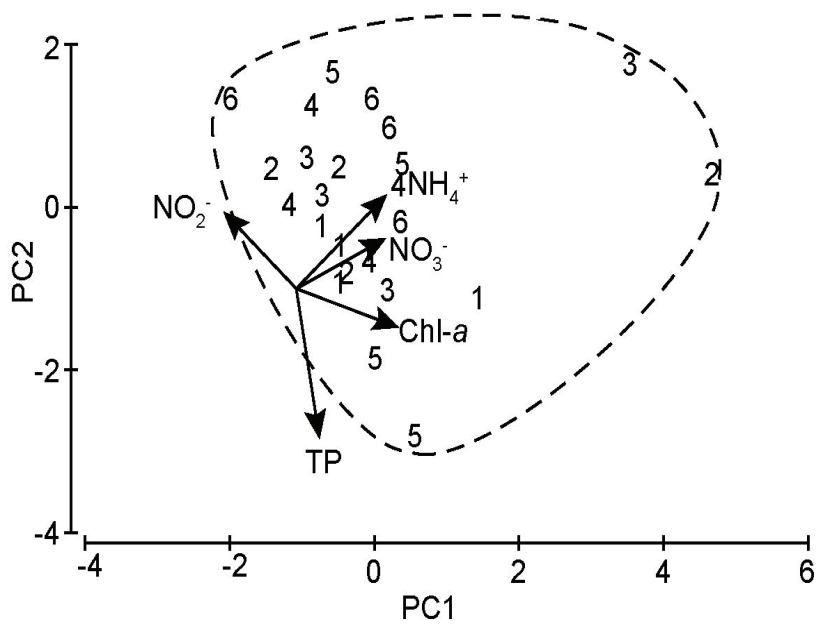

Figure 3. PCA bi-plot of the first two components synthesizing the data of the Chlorophyll-a (Chl-a), Nitrite $\left(\mathrm{NO}_{2}^{-}\right)$, Nitrate $\left(\mathrm{NO}_{3}^{-}\right)^{-}$, Ammonium $\left(\mathrm{NH}_{4}^{+}\right)$and total Phosphorus (TP) at the Maluco river-floodplain system. The samples are classified by intra-annual sampling times (1-6). Dashed line=group.

\section{DISCUSSION}

The lack of the intra-annual variation of physicochemical and biological water variables in the Maluco river-floodplain system has also been reported for other hydraulic altered river-floodplain systems (Jeppesen et al., 2015; Li et al., 2019). In the study area, the maximum concentrations of $\mathrm{Chl}-\mathrm{a}$ occurred during the first three times, but all their values surpassed the hypereutrophic reference value ( $\geq 25 \mu \mathrm{gL}-1)$, according to OECD (1982), throughout the hydrological year (Supplement 1). Also, the nitrogen nutrients levels were below $1 \mathrm{mgL}^{-1}$ throughout the six times sampled (Supplement 1) which is the reference inorganic enrichment value (Wilde et al., 2015; Zhu et al., 2015). Therefore, the intra-annual similarity among the concentrations of $\mathrm{Chl}-a$, nutrients and water level can be related to two years of hydraulic of disconnection between the Grijalva river and the Maluco floodplain due to the fact that maximum WL measured values $(\leq 12 \mathrm{~m})$ promoted the persistence of the hypereutrophic conditions, since the overflow of the bankfull would begin when the Grijalva river reaches $13 \mathrm{~m}$ of WL. Likewise, the persistence in time of the hypereutrophic conditions (Chl-a and TP) in the Maluco river-floodplain system agree with other results in hydraulically altered river-floodplain systems (Pinilla, 2010; Reckendorfer et al., 2013; Li et al., 2019), or with different interannual times of hydraulic connection (McKinney \& Charpentier, 2009). Instead, the variation of $\mathrm{Chl}-\mathrm{a}$ and nutrients in non-perturbed river-floodplain systems differed significantly in relation to WL, mainly between low and high water level (Brito et al., 2014; Tubatsi et al., 2014; Roach et al., 2014; Cruz-Ramírez et al., 2019). Indeed, the maintenance of the water connectivity conditions, natural flow cycles, and flood pulses is indispensable to keep the biogeochemical processes that maintain the ecological functions and services provided by the river-floodplain systems (Junk \& Wantzen, 2004; Marton et al., 2015).

In the Maluco river-floodplain system, the highest values of TP in time could be better explained by the wide fluctuation of its inputs throughout the rivers, as has been registered for others riverine ecosystems (Jarvie et al., 2005; Guan et al., 2016). In the case of the Gri-
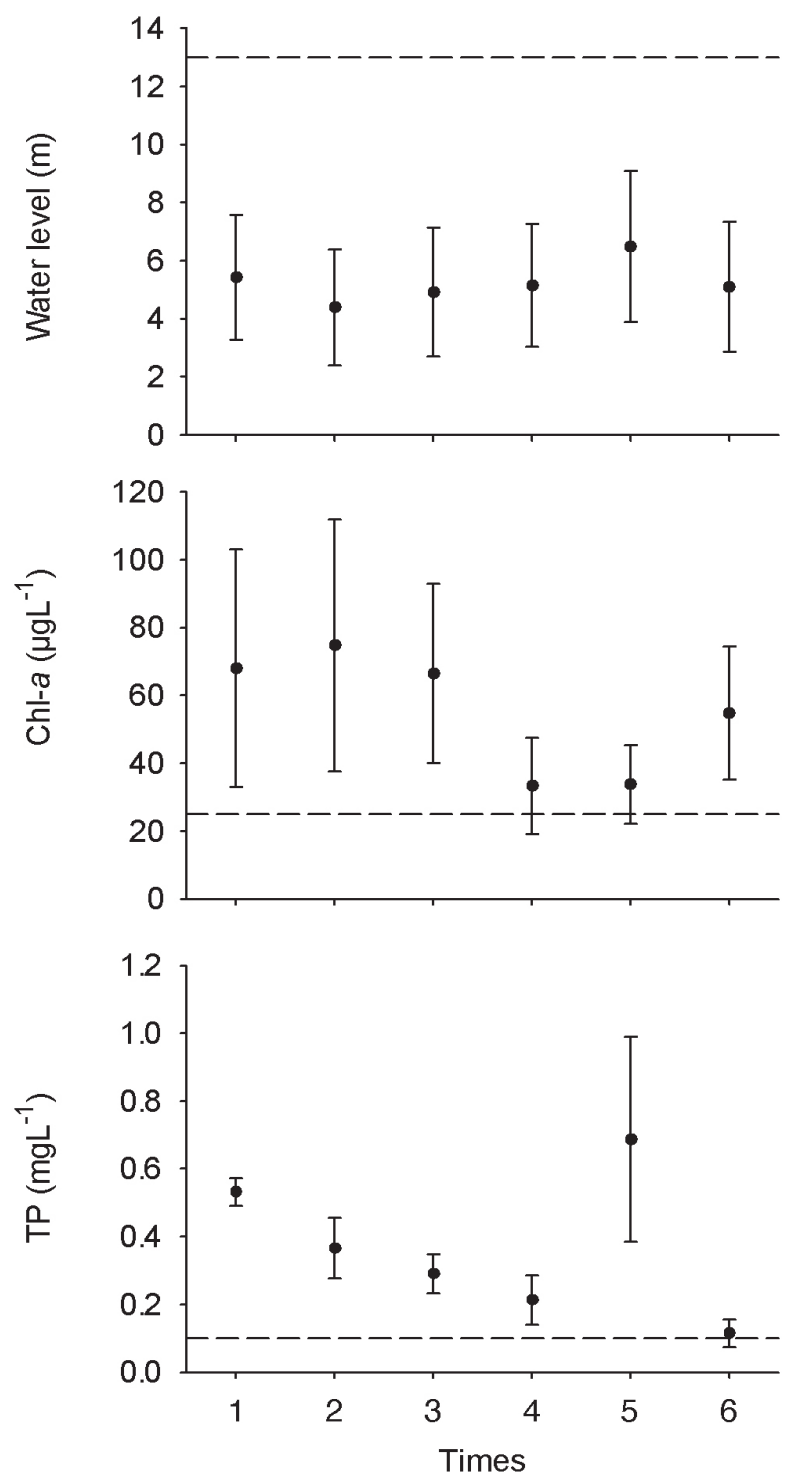

Figure 4. Mean and standard error of water level (WL), Chlorophyll-a (Chl-a), total Phosphorus (TP) in the Maluco river-floodplain system. Dashed lines are the limit to define a condition: bankfull stage $=13 \mathrm{~m}$, hypereutrophic condition of $\mathrm{Chl}-\mathrm{a}=$ $25 \mu \mathrm{gL}^{-1}$ and TP= $0.1 \mathrm{mgL}^{-1}$ (OECD, 1982).

jalva floodplain, the TP concentrations increased significantly during the high water level in sites surrounded by extensive suburban areas (Lázaro-Vázquez et al., 2018). They related the increment of TP to the wastewater discharges, which were mainly caused by the expansion of agricultural areas and growth of human populations.

The restriction of the hydraulic connectivity by the construction of embankments and roads has also been linked to eutrophication processes (Coffin, 2007; Reckendorfer et al., 2013). In this sense, the river-floodplain system in this study kept a hypereutrophic condition independent of the time since all $\mathrm{Chl}-\mathrm{a}$ and TP concentrations were greater than or equal to $25 \mathrm{\mu gL}^{-1}$ and $0.1 \mathrm{mgL}^{-1}$, respectively. Both concentrations correspond to hypereutrophic conditions according to $\mathrm{OECD}$ (1982). 
The additional input of wastewater without treatment intensifies the hypereutrophic processes in aquatic ecosystems isolated hydraulically (Jeppesen et al., 2015). In hydraulically perturbed river-floodplain systems, the reduction of the natural fluctuation in the water levels, combined with a probable low rate nutrient assimilation by primary producers, contributes to exacerbate the eutrophication (Pinilla 2010; Reckendorfer et al., 2013; Jeppesen et al., 2015; Salk et al., 2018). Therefore, the almost permanent hypereutrophic conditions registered in the Maluco river-floodplain system can be linked to the combined effect of the hydraulic disconnection, inputs of wastewater without treatment and shallowness of the ecosystem. However, this rationale will need to be demonstrated for the study area.

In conclusion, the current WL fluctuation in the Maluco river-floodplain system is insufficient to allow the often-recorded intra-annual variation between physicochemical variables and water levels in interconnected river-floodplain systems. The condition of hydraulic isolation helps to explain the intra-annual similarity of $\mathrm{Chl}-a$ and nutrients, the maximum WL values in the study area were lesser than the height (4.5 masl or $13 \mathrm{~m}$ ) of the bankfull stage, and the persistence of hypereutrophic conditions linked to the Chl- $a$ and TP enhancement. This persistence of time-independent hypereutrophic conditions may be a hypothesis to be tested by estimating the minimum input flow of water needed to restore the biogeochemical processes in the Maluco river-floodplain system.

\section{ACKNOWLEDGMENTS}

To Peter B. Bayley for their helpful comments to improve the manuscript. The data come from the project S.G.P.A.-DGIRA-DIA01027/03 funded by Gobierno del Estado de Tabasco and CONAGUA.

\section{REFERENCES}

apha (American Public Health Association). 1998. Standard methods for the examination of water and wastewater. American Public Health Association, American Water Works Association, Water Environment Federation. Washington, DC. $1220 \mathrm{p}$.

Blanton, P. \& W. A. Marcus. 2009. Railroads, roads and lateral disconnection in the river landscapes of the continental United States. Geomorphology 112: 212-227. DOI: 10.1016/j.geomorph.2009.06.008

Brinson, M. M. 1993. A hydrogeomorphic classification for wetland. U.S. Army Corps of Engineers Waterways Experiment Station. Technical Report WRP-DE-4. U.S. Army Engineer Waterways Experiment Station. Vicksburg, MS. 101 p.

Brito, J. G., L. F. Alves \& H. M. V. Espirito Santo. 2014. Seasonal and spatial variations in limnological conditions of a floodplain lake (lake Catalão) connected to both the Solimões and Negro Rivers, Central Amazonia. Acta Amazonica 44 (1): 121-133. DOI: 10.1590/S004459672014000100012

CETIN, M. 2009. A satellite based assessment of the impact of urban expansion around a lagoon. International Journal of Environmental Science and Technology 6 (4): 579-590.

Clatke, K.R. \& R.N. Gorley. 2006 PRIMER v6: User manual/tutorial, Plymouth UK. 190 p.
Clarke, K. R., P. J. Somerfield \& R. N. Gorley. 2008. Testing of null hypotheses in exploratory community analyses: similarity profiles and biota-environment linkage. Journal of Experimental Marine Biology and Ecology 366:56-69. DOI: 10.1016/j.jembe.2008.07.009

Coffin, A. W. 2007. From roadkill to road ecology: A review of the ecological effects of roads. Journal of Transport Geography 15: 396-406. DOI: 10.1016/j.jtrange0.2006.11.006

CONAGUa (Comisión Nacional del Agua). 2012. Banco Nacional de Datos de Aguas Superficiales. Comisión Nacional del Agua. Available online at: https://app.conagua.gob.mx/bandas/ (downloaded May 14, 2018)

Cruz-Ramírez, A. K., M. Á. Salcedo, A. J. Sánchez, E. Barba-Macías \& J. D. Mendoza-Palacios. 2019. Relationship among physicochemical conditions, chlorophyll-a concentration, and water level in a tropical river-floodplain system. International Journal of Environmental Science and Technology 16: 3869-3876. D0I: 10.1007/s13762018-2127-7

de Wilde, M., S. Puijalon, F. Vallier \& G. Bornette. 2015. Physico-chemical consequences of water-level decreases in wetlands. Wetlands 35 : 683-694. https://doi.org/10.1007/s13157-015-0658-y

DodDs, W. K. 2007. Trophic state, eutrophication and nutrient criteria in streams. Trends in Ecology and Evolution 22(12): 669-676. D0l: 10.1016/j.tree.2007.07.010

DOF (Diario Oficial de la Federación). 2018. Acuerdo por el que se dan a conocer los resultados del estudio técnico de las aguas nacionales superficiales en las cuencas hidrológicas Lagartero, Yayahuita, Zacualpa, Papizaca, Presa La Concordia, Selegua, San Miguel, La Concordia, Aguacatenco, Aguzarca, San Pedro, Grande o Salinas, Presa La Angostura, Hondo, Tuxtla Gutiérrez, Suchiapa, Santo Domingo, Presa Chicoasén, Chicoasén, Encajonado, Cintalapa, Soyatenco, Alto Grijalva, De La Venta, Chapopote, Presa Nezahualcóyotl, Tzimbac, Zayula, Presa Peñitas, Paredón, Platanar, Mezcalapa, El Carrizal, Tabasquillo, Cunduacán, Samaría, Caxcuchapa, Basca, Yashijá, Shumulá, Puxcatán, Chacté, De Ios Plátanos, Tulijá, Macuxpana, Almendro, Chilapa, Tacotalpa, Chilapilla, De la Sierra, Pichucalco, Viejo Mezcalapa, Azul, Tzanconeja, Perlas, Comitán, Margaritas, Jatate, Ixcán, Chajul, Lacanjá, San Pedro, Laguna Miramar, Euseba, Caliente, Seco, Santo Domingo, Lacantún, San Pedro, Chixoy, Chocaljah, Chacamax, Usumacinta, Grijalva, Palizada, San Pedro y San Pablo, Laguna del Este, Laguna de Términos, Mamatel, Cumpan y Laguna del Pom y Atasta, pertenecientes a la Región Hidrológica número 30 Grijalva-Usumacinta. 2018, 10 de abril. Edición Matutina. Tercera sección, Poder Ejecutivo, Secretaria de Medio Ambiente y Recursos Naturales. México. Available online at: http://www.dof. gob.mx/index.php?year=2018\&month=04\&day=10 (downloaded January 10, 2011)

Fritz K. M., K. A. Schofield, L. C. Alexander, M. G. McManus, H. E. Golden, C. R. Lane, W. G. Kepner, S. D. LeDuc, J. E. DeMeester \& A. I. Pollard. 2018. Physical and chemical connectivity of streams and riparian wetlands to downstream waters: A synthesis. Journal of the American Water Resources Association 54(2): 323-345. D0I: 10.1111/17521688.12632 
GIL y SAenz, M. 1872. Compendio histórico, geográfico y estadístico del Estado de Tabasco. Tipografía de José M. Abalos, Tabasco. 252 p. Also available at: http://bibliotecadigital.tabasco.gob.mx/items/ show/19473

Guan, Q., L. Wang, F. Wang, B. Pan, N. Song, F. LI \& M. Lu. 2016. Phosphorus in the catchment of high sediment load river: A case of the Yellow River, China. Science of The Total Environment 572: 660-670. D0I: 10.1016/j.scitotenv.2016.06.125

INEGI (Instituto Nacional de Estadística y Geografía). 2011. Anuario estadístico de Tabasco 2011. Instituto Nacional de Estadística, Geografía e Informática, Gobierno del Estado de Tabasco. Tabasco. Available online at: http://www.inegi.org.mx//est/contenidos/espanol/sistemas/aee11/estatal/tab/default.htm (downloaded July 4, 2012).

INEGl (Instituto Nacional de Estadística y Geografía). 2012. Delimitación de las Zonas Metropolitanas de México 2010. Secretaria de Desarrollo Social. Consejo Nacional de Población. México. 216 p.

INEGI (Instituto Nacional de Estadística y Geografía). 2013. Simulador de Flujos de Agua de Cuencas Hidrográficas versión: 3.2. Available online at: http://antares.inegi.org.mx/analisis/red_hidro/siatl/\# (downloaded June 18, 2018)

Jarvie, H. P., M. D. Jürgens, R. J. Williams, C. Neal, J. J. L. Davies, C. Barrett \& J. WHITE. 2005. Role of riverbed sediments as sources and sinks of phosphorus across two major eutrophic UK river basins: The Hampshire Avon and Herefordshire Wye. Journal of Hydrology 304: 51-74. DOI: 10.1016/j.jhydrol.2004.10.002

Jeppesen, E., S. Brucet, L. Naselli-Flores, E. Papastergiadou, K. Stefanidis, T. Nõges, P. Nõges, J. L. Attayde, T. Zohary, J. Coppens, T. Bucak, R. F. Menezes, F. R. S. Freitas, M. Kernan, M. Søndergaard \& M. Beklio-lu. 2015. Ecological impacts of global warming and water abstraction on lakes and reservoirs due to changes in water level and related changes in salinity. Hydrobiologia 750: 201-227. D0I: 10.1007/ s10750-014-2169-x

Junk, W. J. \& K. M. Wantzen. 2004. The flood pulse concept: New aspects, approaches, and applications-an update. In: Welcomme, R. L. \& T. Petr (eds.). Proceedings of the Second International Symposium on the Management of Large Rivers for Fisheries, Vol. 2. Food and Agriculture Organization \& Mekong River Commission. FAO Regional Office for Asia and the Pacific, Bangkok. RAP Publication 2004/16. pp. 117-149.

lázaro-Vázquez, A., M. M. Castillo, A. Jarquín-Sánchez, L. Carrillo \& K. A. CAPPS. 2018. Temporal changes in the hydrology and nutrient concentrations of a large tropical river: Anthropogenic influence in the Lower Grijalva River, Mexico. River Research and Applications 34: 649-660. DOI: 10.1002/rra.3301

Legendre, P. \& L. Legendre. 2003. Numerical Ecology. 2nd ed. Elsevier Science. Amsterdam. 853 p.

LI, Y., Q. Zhang, Y. Cal, Z. TAn, H. Wu, X. LIU \& J. YaO. 2019. Hydrodynamic investigation of surface hydrological connectivity and its effects on the water quality of seasonal lakes: Insights from a complex floodplain setting (Poyang Lake, China). Science of the Total Environment 660: 245-259. D0I: 10.1016/j.scitotenv.2019.01.015
Mantel, S. K., D. A. Hughes \& N. W. J. Muller. 2010. Ecological impacts of small dams on South African rivers Part 1: drivers of change - water quantity and quality. Water $S A 36(3): 351-360$.

McKinney, R. A. \& M. A., Charpentier. 2009. Extent, properties, and landscape setting of geographically isolated wetlands in urban southern New England watersheds. Wetlands Ecology and Management 17(4): 331-344. DOI: 10.1007/s11273-008-9110-x

Marton, J. M., I. F. Creed, D. B. Lewis, C. R. Lane, N. B. Basu, J. C. Matthew, \& B. C. Craft. 2015. Geographically isolated wetlands are important biogeochemical reactors on the landscape. BioScience 65(4): 408418. DOI: 10.1093/biosci/biv009

NavarRo, J. M. \& H. Toledo. 2008. Transformación de la cuenca del río Grijalva. Revista Noticias AMIP 4(16): 11-22.

NoE, G. B., C. R. Hupp \& N. B. RYBICKI. 2013. Hydrogeomorphology influences soil nitrogen and phosphorus mineralization in floodplain wetlands. Ecosystems 16: 75-94. D0I: 10.1007/s10021-012-9597-0

OECD (Organization for Economic Co-operation and Development). 1982. Eutrophication of Waters. Monitoring, Assessment and Control. Organization for Economic Co-operation and Development, Paris. 154 p.

Palma-López, D. J., J. Cisneros, E. Moreno \& J.A. Rincón-Ramirez. 2007. SueIos de Tabasco: su uso y manejo sustentable. Colegio de postgraduados - ISPROTAB - Fundación Produce Tabasco, Tabasco. 199 p.

PInILLA G. 2010. An index of limnological conditions for urban wetlands of Bogotá city, Colombia. Ecological Indicators 10: 848-856. DOI: 10.1016/j.ecolind.2010.01.006

Poff, N. L., J. D. Olden, D. M. Meriitt \& D. M. Pepin. 2007. Homogenization of regional river dynamics by dams and global biodiversity implications. Proceedings of the National Academy of Sciences of the United States of America 104(14): 5732-5737. D0I: 10.1073/ pnas.0609812104

Reckendorfer, W., A. Funk, C. Gschöpf, T. Hein \& F. Schiemer. 2013. Aquatic ecosystem functions of an isolated floodplain and their implications for flood retention and management. Journal of Applied Ecology 50: 119-128. DOI: 10.1111/1365-2664.12029

Roach, K. A., K. 0. Winemiller \& S. E. Davis III. 2014. Autochthonous production in shallow littoral zones of five floodplain rivers: effects of flow, turbidity and nutrients. Freshwater Biology 59: 1278-1293. DOI: 10.1111/fwb.12347

Salk K. R., G. S. BullerJahn, R. M. L. McKay, J.D. Chaffin \& N. E. Ostrom. 2018. Nitrogen cycling in Sandusky, Bay Lake Erie: oscillations between strong and weak export and implications for harmful algal blooms. Biogeosciences 15: 2891-2907 D0l: 10.5194/bg-152891-2018

Sánchez, A. J., M. A. Salcedo, A. A. Macossay-Córtez, Y. Feria-Díaz, L. Vázquez, N. Ovando \& L. Rosado. 2012. Calidad ambiental de la laguna urbana La Pólvora en la cuenca del Río Grijalva. Tecnología y Ciencias del Agua 3(3): 143-152.

Sánchez, A. J., M. A. Salcedo, R. Florido, J. D. Mendoza, V. Ruiz-Carrera \& N. Álvarez-Pliego. 2015. Ciclos de inundación y conservación de servicios ambientales en la cuenca baja de los ríos Grijalva-Usumacinta. ContactoS 97: 5-14 
SAS InstituTE. 2012. JMP Statistics and Graphics Guide. V 10. SAS Institute Inc, North Carolina

SCOR-UNESCO. 1966. Determination of photosynthetic pigments in seawater. Monographs on Oceanographic Methodology. United Nations Educational, Scientific and Cultural Organization, Paris. 69 p.

Sharma, M. P., A. Kumar \& S. Rajvanshi. 2010. Assessment of Trophic State of Lakes: A Case of Mansi Ganga Lake in India. Hydro Nepal 6: 6572. D0l: $10.3126 / \mathrm{hn} . v 6 \mathrm{i} 0.4198$

TABACHNICK, B. \& L. FideLL. 2014. Using multivariate statistics. 6th ed. Pearson Education. United Kingdom. 1056 p.

Thomaz, S. M., L. M. BINI \& R. L. BozelLI. 2007. Floods increase similarity among aquatic habitats in rivers-floodplain systems. Hydrobiologia 579: 1-13. DOl: 10.1007/s10750-006-0285-y
TubatSI, G., M. C. Bonyongo \& M. GondWE. 2014. Water quality dynamics in the Boro-Thamalakane-Boteti river system, northern Botswana. African Journal of Aquatic Science 39(4): 351-360. DOI: 10.2989/16085914.2014.960791

Weilhoefer, Ch. L., P. Yangdong \& S. Eppard 2008. The effects of river floodwaters on floodplain wetland water quality and diatom assemblages. Wetlands 28(2): 473-486. DOI: 10.1672/07-114.1

Zhu, Q. D., J. H.Sun, G. F. HuA, J. H. Wang \& H. Wang. 2015. Runoff characteristics and non-point source pollution analysis in the Taihu Lake Basin: a case study of the town of Xueyan, China. Environmental Science and Pollution Research 22(19): 15029-15036. D0I.10.1007/s11356-015-4709-y 